\title{
ANNE BOOTH \\ Splitting, splitting and splitting again A brief history of the development of regional government in Indonesia since independence
}

The government of President B.J. Habibie, during its brief period in office in 1998-1999, passed two laws on regional government and centre-regional financial relations (Laws Nos. 22 and 25, 1999). At the time, few observers realized just how far-reaching the consequences of this legislation would be; indeed after Habibie left office, some thought that the laws would never be implemented. The two presidents who succeeded Habibie were both Javanese, and neither appeared to be strongly supportive of the legislation; indeed Megawati was overtly hostile. But the demand for fundamental reform of the way Indonesia was governed, both in the national parliament and in the regions, was too strong to be resisted, and implementation went ahead in $2001 .{ }^{1}$ Nine years later, it is clear that the landscape of regional government and regional finance has changed considerably, in ways which the originators of the 1999 legislation probably did not anticipate. Unsurprisingly, the consequences of these changes continue to be much debated, both in Indonesia and abroad. ${ }^{2}$

The purpose of this article is not to review all these debates in detail, but rather to focus on one aspect of the changes which have occurred since the

1 While the strongest supporters of the legislation were from outside Java, including of course President Habibie himself, there were also many Javanese who supported the need for change, not least in the Department of the Interior, where the legislation was drawn up. In addition as Schulte Nordholt (2004:37) has argued, Golkar, the dominant party during the Soeharto era, lost heavily in Java in the 1999 election, and supported the legislation in the hope of maintaining its power bases outside Java.

2 From being a relatively neglected topic during the Soeharto era, the literature on decentralization and regional autonomy in Indonesia has burgeoned since 2000. Edited volumes include Sakai (2002), Aspinall and Fealy (2003), Kingsbury and Aveling (2003), Erb, Faucher and Soelistiyanto (2005) and Schulte Nordholt and Van Klinken (2007). Most of these volumes focus on the political aspects of the changes which have occurred since 2001. Erb and Soelistiyanto (2009) contains a number of papers which examine the direct elections of regional leaders since 2004 in the context of evolving regional power structures.

ANNE вOOTH is Professor of Economics (with reference to Asia) at the School of Oriental and African Studies, University of London. Her main field of academic interest is economic development of Southeast Asia in the twentieth century. She is the author of The Indonesian economy in the nineteenth and twentieth centuries: A history of missed opportunities, Basingstoke: Macmillan, 1998 and of Colonial legacies: Economic and social development in East and Southeast Asia, Honolulu: University of Hawai'i Press, 2007. Professor Booth may be reached at ab10@soas.ac.uk. 
passage of these laws, namely the splitting of provinces and districts into smaller units. ${ }^{3}$ The article points out that this process has in fact been going on since the 1950s, but has taken on new momentum in the last decade, especially at the sub-provincial levels of government. When Soeharto left office in May 1998, there were 27 provinces in Indonesia, compared with 12 in the early 1950s. Since 1998, one province (East Timor) has achieved independence, and seven new provinces have been created, all but one outside Java. Between 1995 and 2009, 37 new urban districts (kota) and 168 new rural districts (kabupaten) have emerged. Almost all these new urban and rural districts have been created outside Java (Table 1).

Table 1. Number of districts (kabupaten and kota)

\begin{tabular}{lrrr}
\hline Region & 1961 & 1995 & 2009 \\
\hline Kota & 22 & 25 & 34 \\
Java & 17 & 21 & 34 \\
Sumatra & 5 & 5 & 9 \\
Kalimantan & 4 & 6 & 11 \\
Sulawesi & 0 & 2 & 4 \\
Bali/Nusatenggara & 1 & 1 & 4 \\
Maluku & n/a & 1 & 2 \\
Papua & 49 & 61 & 98 \\
\hline Indonesia & & & 84 \\
Kabupaten & 80 & 82 & 116 \\
Java & 47 & 52 & 46 \\
Sumatra & 21 & 23 & 62 \\
Kalimantan & 33 & 33 & 36 \\
Sulawesi & 26 & 4 & 16 \\
Bali/Nusatenggara & 3 & 9 & 37 \\
Maluku & n/a & 229 & 397 \\
Papua & $210^{*}$ & & \\
\hline Indonesia & & &
\end{tabular}

* excludes Irian Jaya/Papua

Source 1961: Central Bureau of Statistics 1963; source 1995: Central Bureau of Statistics 1996; Central Bureau of Statistics 1997; source 2009: Central Board of Statistics 2009: Table 1.2.

What has driven the process of the creation of new provinces and districts in the post-Soeharto era? Why has that process occurred almost entirely outside Java? What will be the implications for delivery of services to populations

3 The Indonesian word which has been used to describe this process is pemekaran which means blossoming. Some official publications have used the term pecahan for the splitting of provinces and districts into smaller units; that seems a more accurate word for what has actually occurred. The English word 'splitting' will be used in this article. The word 'district' will be used to refer to both kabupaten and kota (kotamadya/kotapradja), or 'second-level' government (daerah tingkat dua) as they were known until 1999. 
across the Indonesian archipelago? This article seeks to cast some light on these questions. But first, in order to set the post-1998 developments in context, the article examines the way regional and local government developed in Indonesia after independence.

\section{Development of regional government after 1950}

To many observers both at the time and later, it would have been logical for the newly independent Indonesian republic to have chosen a federal constitutional structure in 1949. Indeed there were, as Feith (1962:72) argued, some convinced advocates of a federal structure within the Republican leadership, 'and Prime Minister Hatta appeared at times to be one of them'. ${ }^{4}$ But the Dutch stratagem of creating a federal Indonesian state in 1945-1946 effectively discredited the concept of federalism in the eyes of the nationalist leadership. Legge (1961:7) pointed out that 'in developing their proposals for a federal Indonesia after 1945 the Dutch were not building on prewar foundations'. In spite of some devolution of powers to the provincial administrations in Java in the years from 1900 to 1930, the colonial government had certainly never been federal in concept or in practice. Rather it had been based on a highly centralist hierarchical system whereby the heads of each level of government were accountable to those above, and where elected councils played only a very weak role, both in the selection of these heads and in monitoring their behaviour (Maryanov 1959:140-52).

There can be little doubt that 'divide-and-rule tactics did in fact enter strongly' into the 1945 decision to convert the archipelago into a federation (Taylor 1960:330). By far the largest of the federal units created by the Dutch was the state of East Indonesia, and by the end of 1947 responsibility for finance, justice, general economic affairs, police, education, information, health, social affairs, industry, shipping, forestry, irrigation and agrarian affairs had all been delegated to the regional government, although in practice, as George McTurnan Kahin (1952:60) stressed, the exercise of all these powers was greatly vitiated by the numerous general and specific powers reserved to the central government in Batavia. It was not by accident that Eastern Indonesia was chosen as the model for the Dutch experiment in federalism. ${ }^{5}$ As George McTurnan Kahin showed in his classic study, the

4 In an interview in the Jakarta Post after Soeharto had left office (18 November 1999), Feith pointed out that Hatta 'who played the central role in dissolving that federal structure, was actually a federalist'. Lev (1996:148-57) discusses the debates between Raden Supomo and Mohammad Yamin over the 1945 constitution; Yamin wished to follow more explicitly the American model.

5 In his study of the formation and subsequent history of the state of East Indonesia, Ide Anak Agung Gde Agung (1996:798) states that Van Mook's behaviour in creating states and regions within the Republic of Indonesia's territory 'sounded the death knell for the concept of a federa- 
Dutch found it easier to deal with the nationalist movement there than in Java or Sumatra. Although some traditional leaders in Sulawesi supported the Republic, the Dutch were able to muster sufficient force to overcome their resistance, sometimes by replacing leaders sympathetic to the Republic with those who were more pliant.

So cynical were the means used by the Dutch to establish their federal state in Eastern Indonesia and elsewhere that the nationalists, not surprisingly, equated federalism with collaboration. As Feith (1962:71) argued, when the form of the independent state came to be finalized in 1949, the issue was not one of a federal versus a unitary constitutional form. Rather it became one of support for an independent republic versus cooperation with Dutch policies of divide and rule. However Feith also pointed out that the appeal of the anti-federalist case was 'undoubtedly greatest in Java'. This was because the federal units established by the Dutch in Java were transparently artificial, and also because the independence struggle generally had come to take on a deeper importance in Java than elsewhere.

Thus the federal option was rejected by the new republic and a provisional unitary constitution was adopted in 1950. While, as Maryanov (1958:31) argued, 'the spirit of 1950 was to make the unitary state work', discussion continued regarding a permanent constitutional framework for Indonesia. ${ }^{6}$ But while talks continued, decisions had to be made about appropriate administrative structures for the new nation. It was decided that Jakarta, rather than Yogyakarta should be the new capital, and that Java should continue to be divided into three provinces, as in the late colonial era. ${ }^{7}$ But the new capital would be given the status of a province, and as a concession to the population of Yogyakarta and to its sultan who had participated so prominently in the independence struggle, the sultanate would be designated a 'special region' with provincial status. ${ }^{8}$ Most of the sub-provincial units in Java (regencies or kabupaten, kawedanan, kecamatan, and kelurahan) were also kept with few alterations, although there was a trend towards amalgamation of keluruhan in Java. ${ }^{9}$

tion in Indonesia'. See also Chauvel (1997) for a discussion of the failure of the Dutch attempt at creating a federal state in the years from 1946 to 1949. That some politicians from the Soeharto era had an interest in the Van Mook proposals is confirmed by Mboi (2009:42). He states that when he went to the Netherlands in 1989, after a period as governor of East Nusatenggara, he was asked by Soepardjo Rustam, then the Minister of Internal Affairs, to look at the Van Mook proposals again and report on what relevance they still held for modern Indonesia.

$6 \quad$ An extended analysis of the constitutional debates of the 1950s can be found in Nasution 1992.

7 The province of West Java was created in 1926, after the passage of the 1922 Government Reform Act; the provinces of Central and East Java were created later. The principalities of Surakarta and Yogyakarta were given the status of 'governments' (Niessen 1999:48-9).

8 Quinn (2003:170-2) discusses the reasons why Yogyakarta was treated differently from the neighbouring sunanate of Surakarta in the early post-independence era.

9 Amalgamation of villages was accompanied by the introduction of elections for all village officials on the basis of universal adult suffrage (George McTurnan Kahin 1952:472). Outside Java, the pace of change was slower, although some amalgamation of small villages into larger units 
Outside Java the problems were more difficult, as provinces had not been formed in the colonial era, and boundaries were often more contested. It was decided to carve Sumatra into three provinces (North, Central and South), while Kalimantan, Sulawesi, the Moluccas, and the Lesser Sundas (Bali and Nusatenggara) each became one province. As Feith (1962:99) pointed out this arrangement 'paid little heed to regional or ethnic group feeling' and soon provoked strong reactions which in several instances led to armed revolt. In Aceh there was particular resentment among the leaders who had sided with the republican forces from 1945 to 1949; they felt betrayed when the promise of provincial status made to them in the late 1940s was withdrawn, and Aceh was incorporated into the province of North Sumatra (Kell 1995:10-1; Miller 2006:293). Other parts of Sumatra feared domination by particular ethnic groups, and in many parts of both Java and Sumatra, as well as in other regions, the Darul Islam struggle, which sought the creation of an Islamic state, gathered many supporters.

These resentments erupted into armed struggle and the establishment of an alternative government in the province of West Sumatra in 1957. The government reacted by offering provincial status to what had been the residencies of Riau and Jambi, although the loyalties of the populations in both provinces were divided between the Jakarta government and the rebels (Audrey Kahin 1999:192). The resource-rich province of Kalimantan was also divided into four provinces in 1957. Aceh was also awarded provincial status. Sulawesi was divided into two, and Kalimantan was divided into four provinces. ${ }^{10}$ The Lesser Sundas became three provinces (Bali, West Nusatenggara, and East Nusatenggara). Thus by the time of the first post-independence population census in 1961, there were 22 provinces, although one was still under Dutch control (Irian Barat, or West Irian as it was then known). More divisions took place in the early 1960s when the two provinces in Sulawesi were divided into four, and Lampung and Bengkulu were split off from South Sumatra. ${ }^{11}$ Each of these provinces was in turn divided into kabupaten

probably took place during the first two decades of independence. In colonial Java there was also a further layer of government in Java between the province and the district called the residency. This layer survived into the post-independence era; the head was usually referred to as an 'assistant governor'.

10 For a discussion of the splitting of Kalimantan into four provinces, see Mubyarto and Baswir 1989:503. Central Kalimantan was formed a few months after the other three in 1957; the main reason for separate provincial status for this isolated and lightly populated region appears to have been the fact that the population was mainly Dayak, rather than Banjarese.

11 The splitting of Sulawesi into four provinces had been preceded by the formation of several new kabupaten in both Central and Southeast Sulawesi in the latter part of the 1950s (Hill 1989: Chapters 22 and 25). Southeast Sulawesi had been one kabupaten after independence; in 1959 it was split into four and the new province was created in 1964. Bengkulu, which had the smallest population of any province in 1971, appears to have been given provincial status (along with Lampung) in 1964 because of pressure from Soekarno's second wife, Fatmawati, who was a native of Bengkulu and whom Soekarno met during his exile there in the late 1930s. 
and kota, and these in turn were divided into kecamatan and village units. Boundaries in Java remained largely unchanged, and because the populations of the three provinces in Java were so much larger than any province outside Java, populations of kabupaten and kota were also on average much larger. In Java in 1961, the average population of a district-level government was over 600,000 compared with around 250,000 in Sumatra and a lower average elsewhere (Table 2).

Table 2. Average population size of districts, 1961, 1995, and 2009 (x 1000)

\begin{tabular}{lrrrc}
\hline Region & 1961 & 1995 & 2009 & Average size (sq. km) \\
\hline Java & 618 & 1,072 & 1,137 & 1,097 \\
Sumatra & 246 & 559 & 331 & 3,205 \\
Kalimantan & 158 & 374 & 238 & 9,894 \\
Sulawesi & 191 & 352 & 230 & 2,582 \\
Bali/Nusatenggara & 214 & 361 & 315 & 1,827 \\
Maluku & 197 & 417 & 114 & 3,945 \\
Papua & n/a & 194 & 77 & 10,668 \\
\hline Indonesia & $372^{*}$ & 669 & 462 & 3,860 \\
\hline
\end{tabular}

* Excludes Irian Jaya/Papua.

Source 1961: Central Bureau of Statistics 1963; source 1995: Central Bureau of Statistics 1996; Central Bureau of Statistics 1997; source 2008: Central Board of Statistics 2009: Tables 1.3, 2.3.

The splitting of provinces in the 1950s can be viewed as 'divide and rule' tactics, implemented by a central government facing armed insurrections in several regions and the threat of more violent outbreaks in others. But creating more provinces and districts did little to remove the grievances felt by many outside Java towards the central government as the economy deteriorated over the 1960s. The main resentments were well summarized by Feith (1962:487-8):

Over the whole period which followed the formation of the unitary state there was a crescendo of demands from the provinces and regions. Provincial spokesmen denounced 'Jakarta' for not giving them enough autonomy. They castigated it for its cumbersome administrative procedures, for the fact that governmental leaders in the regions had often to fly to Jakarta for approval of quite minor decisions of policy. They criticised the central government for the supervision which it exercised over their affairs through its pamong pradja representatives, governors, residents, regents and so on. Above all they reproached the center for not giving them enough money.

From a strictly economic point of view, much of this discontent was caused by the fact that, from independence onwards, Java was producing only a small 
fraction of the nation's exports, but was consuming the bulk of the imports. This led to constant complaints by the exporting regions, that although they were the main generators of the nation's wealth, they were neglected when decisions were made on government expenditures. The whole issue of regional finance was subjected to detailed investigation in the mid-1950s by a committee headed by M. Nasroen, a senior civil servant in the Department of the Interior, and many of the findings of this committee were incorporated in Law No. 32 of 1956, concerning financial relations between the centre and the autonomous regions. ${ }^{12}$ This law did in fact make some important concessions to the regions in that it allowed the proceeds of both income taxes and foreign trade taxes to be shared between provinces where the tax revenues originated and the centre. Unfortunately as Legge (1961:193) pointed out, implementation of this law was slow. In particular little progress was made in laying down rules for the sharing of the most important taxes between the centre and the regions.

As well as new legislation concerning financial relations between the centre and the regions, a new local government law passed at the end of 1956 (Law No. 1 of 1957) made important modifications to established procedures governing the relationship between appointed regional heads (kepala daerah) and regional parliaments. Legge (1961:52) viewed the new legislation as an attempt to weaken the office of the regional heads and strengthen the parliaments, and by implication the role of the political parties that expected to dominate the elected parliaments. Local government elections did in fact take place in Java during 1957, but when President Soekarno decided to return to the 1945 constitution in July 1959, it was clear that the powers of both the central and the regional parliaments would be drastically curtailed. ${ }^{13}$ It was not until the demise of President Soeharto almost four decades later that new legislation became possible. Law No. 22 of 1999 can thus be seen as trying to achieve the same goals as Law No. 1 of 1957, albeit in a rather different political and economic setting.

By the early 1960s the army had demonstrated its capacity to impose the writ of the central government in most parts of the archipelago, and most of the regional rebellions in Sumatra and Sulawesi were brought under control. But increasing inflation and a hugely overvalued exchange rate led to increased smuggling, much of it carried on with army connivance. Increasingly the dissident regions found that they could make common cause with the anti-Communist military (in whose senior ranks there were after all a fair sprinkling of nonJavanese) in their continuing struggles with the centre. As Mackie (1980:674-5) summed up the situation, a politics of manipulation and compromise replaced the earlier confrontational pattern. A system of 'de facto federalism' came to

12 See Paauw 1960, Appendix E for a discussion of this legislation.

13 For a discussion of the 1957 legislation, and its fate during the Guided Democracy period, see Holland 1999:204-6. 
apply, where compromise and ad hocery affected economic as well as political aspects of the relationship between the centre and the regions. Bargains over the imposition of illegal taxes and the sharing of revenues from smuggling were struck between local officials, the military and civilian representatives of the central government, with the last being usually by far the weakest partner. The centre indeed had little option but to turn a blind eye to much of what was going on because it had no effective means of enforcing central government laws and regulations even where its official representatives in the form of governors, bupati, camat and so on might have wished to do so.

\section{Achievements and failings of the Soeharto era}

There is universal agreement that the Soeharto years were marked by 'an inexorable trend towards recentralisation of power' (Mackie 1980:676), and a crucial role in this process was played by the system of central grants to the regions. Over the 1960s the value of such grants had been eroded by inflation, and by 1968 central grants were virtually worthless. Beginning in 1969, the central government began a series of programmes whose purpose was to enable provincial, district and village administrations to carry out much needed rehabilitation of infrastructure (roads, bridges, irrigation facilities, village halls), using earmarked grants from the centre. It was envisaged that labourintensive construction techniques would be used, and that much of the work would be carried out in the agricultural slack season. Thus the programmes were intended to have a significant employment generation effect. ${ }^{14}$

These programmes (which became known by the acronym INPRES) were important not just because they demonstrated the concern of the centre for the parlous state of local infrastructure, especially in rural areas, and also the centre's concern over the problem of rural under-employment. They were also important because of the way that the grants were allocated. Detailed guidelines for allocation procedures were drawn up by the Planning Bureau in Jakarta and by central departments and, with very few exceptions, these were adhered to, at least until the latter part of the 1980s. For their part, local governments could rely on a guaranteed flow of funds from the centre from year to year. They could, within the guidelines laid down from the centre, begin to make rolling plans for infrastructure development over several

14 For a discussion of the aims and implementation of the original INPRES Kabupaten Programme, see De Wit 1973; Patten, Dapice and Falcon 1980. These papers were written by advisers who were closely connected with the original INPRES programmes and give an outline of the way the projects were implemented, at least in the early years. From the outset, it was made clear that the grants were not to be used for office buildings or vehicles, although other funds at the disposal of kota/kabupaten governments including the land tax (IPEDA) revenues were used for office buildings in many cases. 
years, secure in the knowledge that the funds would be available.

After the first oil shock in 1973-1974, which coincided with the beginning of the second five-year plan of the Soeharto era, new INPRES programmes were initiated which were directed to specific types of infrastructure. The largest was the INPRES Sekolah Dasar which provided funding for the construction of a simple three-roomed school house in every village unit in the country, using a plan which was drawn up jointly by the Department of Education and the Department of Public Works in Jakarta, and sent to every province in the country. A parallel programme provided funds for the construction of primary health care centres. Again clear guidelines were laid down on the allocation of funds and the construction of facilities, supposedly to minimize corruption and waste. As these programmes accelerated, together with the growth in expenditure on development projects implemented by agencies of the central government, people everywhere in the archipelago began to see some evidence that the oil wealth accruing to the government was being used on facilities which would directly benefit them and their families. But the grant allocation system remained highly centralized with the central government maintaining tight controls over grant allocations, and also over how the money was spent.

It is perhaps surprising that the oil boom of the 1970s did not bring with it any demand on the part of the producing provinces to retain a larger share of the profits. In fact, over the oil boom period (1973-1981), most of the oil came from two provinces, Riau in Central Sumatra and East Kalimantan. Both were small and lacking in strong regional identities or in much tradition of regional nationalism. In both provinces, but especially in East Kalimantan, a large number of migrants from other parts of the country were drawn into the oil and logging sectors and related activities, and in both provinces ethnic Javanese held key positions in the civilian and military bureaucracies. ${ }^{15}$ Although there was debate about the extent to which the oil boom 'spilled over' to the local populations in both these provinces, there were sufficient signs of improvement in infrastructure and living standards to convince the majority of the indigenous population that they were benefiting from the exploitation of their provinces' natural resources even if these benefits were modest in comparison with the total value of their oil exports. ${ }^{16}$

15 From the 1960s through to the end of the century, the demographic structure of East Kalimantan evolved in a very different way from that of other provinces in Indonesia. By 2000, 70 per cent of the population were living in the four main cities, and the urban populations were mainly of Javanese, Buginese and Banjarese origin (Morishita 2008:89-90). Large numbers of migrants from Java and other parts of Sumatra also flooded into Riau, giving rise to an ongoing debate in the post-Soeharto era as to who exactly is an orang Riau (Ford 2003).

16 For more detailed discussions of economic development in the resource-rich provinces until the mid-1980s, see Chapters 3-6 of Hill 1989. Although these chapters were written by Indonesian scholars, they demonstrated a remarkable lack of concern over the issue of sharing the resource rents, which suggests that the provincial elites in provinces such as Aceh and Riau were not unhappy with the system prevailing at the time. 
As world oil prices began to fall in the early 1980s, the Indonesian government was forced into making cuts in its budgetary expenditures to compensate for falling oil revenues. By and large, both central and regional governments accepted the decline in real resources available to them through the 1980s as the inevitable consequence of the fiscal austerity necessitated by the decline in oil prices. ${ }^{17}$ Severe social unrest was minimized because, in contrast to countries such as Mexico, Venezuela or Nigeria, Indonesia had not used its oil revenues to subsidize prices of basic needs so that budgetary cutbacks did not involve massive increases in prices of staple foods or other essential services. The period of the fifth five-year plan (1989-1994) saw a considerable growth in INPRES expenditures relative to total domestic revenues and total government development expenditure. By 1995-1996, they accounted for over 25 per cent of the development budget. Most categories of INPRES expenditures shared in the growth over 1989-1994, although the fastest growth was experienced by the INPRES Jalan, which was targeted towards rehabilitation and extension of the road network (Shah and Qureshi 1994: Chapter 4; Booth 1996: Table 11.1). In 1994-1995, a new INPRES programme was introduced which targeted particularly those villages which were considered to have been 'left behind', that is those that had not benefited from the rapid economic growth of the past two decades. ${ }^{18}$ This new programme reflected growing official concern with spatial inequities in economic development, and especially with what was seen as the 'problem' of Eastern Indonesia.

During the 32 years of Soeharto's presidency, only one new province was created (East Timor) and this was the result of territorial conquest of the former Portuguese colony, rather than splitting an existing province. There was some increase in the numbers of kabupaten and kotamadya, mainly outside Java (Table 1). New kotamadya reflected the accelerating pace of urbanization, although the central government was often slow to grant kotamadya status even to areas which were clearly urban in terms of population density and function. As population grew between 1961 and the mid-1990s, the average population of both provinces and districts also grew. By 1995, the average size of a district (daerah tingkat dua) in Java was over one million and around 560,000 in Sumatra. Rapid increases in the average population of a district also occurred in other regions (Table 2).

The most dramatic change in the number of local government units over the Soeharto era occurred at the village level. In 1969-1970 there were around 44,500 villages in Indonesia according to the official definition (Table 3).

17 The central government initiated a process of tax reform in the mid-1980s, which involved the introduction of a value-added tax, and substantial reform of the personal and corporate income tax. There was however no attempt to reform the system of local government finance.

18 For a discussion of the INPRES Desa Tertinggal, see Pangestu and Azis 1994:32. 
By 1983-1984 this had increased to 66,000 although there was some decline after 1988-1989. The creation of new 'villages', especially outside Java, was often controversial in that it was viewed as a deliberate attempt by the central government to impose an essentially Javanese construct on indigenous systems in other regions. ${ }^{19}$ Certainly there does appear to have been an official policy over the 1980s to prevent villages from exceeding a certain size in terms of population, and to divide villages up once the maximum had been reached. In some of the lightly populated regions outside Java, officials were concerned that villages should not cover too large a geographical area. These concerns no doubt reflected deeper worries about the re-emergence of radical organizations, whether political or religious, at the grass roots. But these worries did not extend to provinces and districts, whose populations grew considerably between the 1960s and the 1990s.

Table 3. Number of villages, per capita village grant and percentage of total grant accruing to Java

\begin{tabular}{lccc}
\hline Fiscal year & Number of villages & $\begin{array}{c}\text { Per capita grant } \\
\text { (x Rp. 1000) }\end{array}$ & $\begin{array}{c}\text { Percentage of } \\
\text { total grants } \\
\text { accruing to Java }\end{array}$ \\
\hline $1969-1970$ & 44,478 & 100 & 46.4 \\
$1973-1974$ & 45,587 & 100 & 48.9 \\
$1978-1979$ & 61,296 & 350 & 38.6 \\
$1983-1984$ & 66,437 & 1,250 & 36.8 \\
$1988-1989$ & 66,744 & 1,500 & 36.8 \\
$1993-1994$ & 63,721 & 5,500 & 36.4 \\
$1996-1997$ & 64,404 & 6,500 & 39.3 \\
2009 & 76,546 & n/a & n/a \\
\hline
\end{tabular}

Sources: Department of Information 1993: Table XIV-2; Department of Information 1998: Table IX-16. 2009 figures from Central Board of Statistics 2009: Table 1.2.

By the early 1990s, it was clear that there was considerable unrest in many parts of the country over the system of regional and local government which had grown up under Soeharto (Booth 2003:185-94). In the resource-rich parts of the country, the old grievances about Javanese exploitation had not gone away, and when provincial poverty estimates were published in the early 1990s, the problem of 'rich provinces and poor people' became more obvious. Although the headcount measure of poverty was lower than the national average in Aceh, Riau and East Kalimantan, it was much higher in Irian Jaya in 1996 (Booth 2004: Table 4).

19 Law No. 5/1979 set out the principles of the New Order regarding village government; Antlöv (2003:195) argues that with the passage of the law, 'village affairs were brought firmly under the supervision and control of higher authorities, and village structures were recast within a single homogeneous mould'. 
And in East Kalimantan, which shared a long border with East Malaysia, differences in poverty levels between East Kalimantan and the states of East Malaysia were considerable in spite of the fact that per capita regional GDP (in US dollar terms) was higher in East Kalimantan than in Sabah and Sarawak (Booth 2003: Table 6). By the early 1990s, many of the INPRES grants were skewed to regions outside Java, but this did little to assuage resentments in many parts of the outer islands (Table 4 ) ${ }^{20}$ At the same time, the lower per capita allocations to the more densely settled regions, especially on Java, were leading to grievances there. These perceived inequalities, combined with evidence of growing corruption at the province and district level, was building into demands for a change in the heavily centralized system when the economic crisis erupted in late 1997.

Table 4. Percentage of INPRES grants accruing to Java, 1973-1974, 1978-1979, 1989-1990 and 1996-1997

\begin{tabular}{lcccc}
\hline INPRES & $1973-1974$ & $1978-1979$ & $1989-1990$ & $1996-1997$ \\
\hline Grant by type & & & & \\
\hline Village & 48.9 & 38.6 & 36.9 & 39.3 \\
District & 44.3 & 58.9 & 59.2 & 54.9 \\
Roads (district) & $\mathrm{n} / \mathrm{a}$ & 7.0 & 25.3 & 15.4 \\
Provincial & 15.5 & 28.6 & 18.5 & 16.5 \\
Roads (provincial) & $\mathrm{n} / \mathrm{a}$ & $\mathrm{n} / \mathrm{a}$ & 23.8 & 12.6 \\
Assistance to schools & n/a & n/a & n/a & 42.9 \\
Villages left behind & n/a & n/a & n/a & 27.8 \\
\hline
\end{tabular}

Source: Department of Information 1993: Table XIV-9 to XIV-33; Department of Information 1998: Tables IX-3 to IX-20.

\section{Implementation of the 1999 legislation}

The years from 1998 to 2000 were some of the most troubled in Indonesia since independence. The decision taken by President Habibie in 1999 to allow the people of East Timor to vote on a referendum giving them the choice of special autonomy or independence resulted in a huge majority voting for independence. Enraged militias backed by elements in the Indonesian army destroyed infrastructure and killed civilians across the province. A United Nations force moved in to restore order and prepare the territory for eventual

20 Already by the 1980s there was a tendency for the smaller, less densely settled provinces to receive higher INPRES grants both in per capita terms and relative to GDP. For evidence that there was no 'Java bias' in the allocation of INPRES grants, see Booth 2003:189-90; Silver, Azis and Schroeder 2001:354-6. 
nationhood. Across much of Indonesia, violence increased, with a growing toll of death and destruction. Some of this violence was openly secessionist, while in other regions the conflict was religious or ethnic, especially between Christian and Muslim groups (Van Klinken 2007:4-7). Anti-Chinese violence flared in Jakarta and some other towns in Java in May 1998, although this appears to have been stirred up by a small group within the armed forces. The violence was quickly brought under control.

Fear of secessionist movements outside Java was no doubt one reason why the administration of President Wahid pressed ahead with implementation of decentralization. Certainly many at the centre felt that pushing more resources to sub-provincial governments would weaken the appeal of secession by provinces (Marks 2009:43-4). But the greater powers which the legislation gave to districts did not prevent demands for new provinces, and by 2007, seven new provinces had been created. In several cases the new provinces were far from being resource-rich and had not displayed marked secessionist tendencies in the Soeharto era. Other factors were also in play. In the case of West Sulawesi and Gorontalo, the support of Habibie was probably crucial. He had close family connections with Gorontalo, and was sympathetic to arguments that the region was distinct from North Sulawesi in terms of both religion and ethnicity (Kimura 2007:92).

It is likely that Habibie's close association with the island of Sulawesi also facilitated the formation of the new province of West Sulawesi, which was split from South Sulawesi. The old kabupaten of Madjene, Mamuju and Polmas had always felt cut off and neglected, with poor communications to the rest of South Sulawesi. Intensive lobbying by local elites was successful not just in securing the new province, but also in creating two new kabupaten out of the existing three. But attempts to create a new province out of the kabupaten in the north-eastern part of South Sulawesi were not successful (Roth 2007:146-7). An important reason for the failure was that conflicts arose between the districts of Luwu and Tanah Toraja over the composition of the new province; the two regions had different religious and ethnic identities which could not easily be reconciled. In addition, Law No. 32 of 2004, passed during the administration of President Megawati, placed curbs on the pemakaran process at both provincial and district level.

The decision to create the new province of North Maluku resulted from the violence which flared across the old province in the late 1990s, which gave local elites in the north, where the populations are largely Muslim, a strong argument for splitting, although creating a new province did not prevent further violence between ethnic groups. ${ }^{21}$ The desire of local populations to have greater control over natural resources was certainly one reason

21 For a discussion of the conflicts which arose in North Maluku after the province was created, see Smith 2009. 
for the creation of Bangka/Belitung province from the old province of South Sumatra. People on the islands of Riau had always felt separate, ethnically and geographically, from the mainland, and local elites no doubt reasoned that in a separate province they would be better able to exploit their strategic location close to Singapore. Ford (2003:144) found overwhelming support for a separate province among the island populations, who felt that separation would create a province with a stronger cultural identity, which in turn should improve community services.

In Java only one new province was created: the old residency of Banten was split off from West Java. West Java was the largest province in Indonesia in terms of population in the 1990s, and many felt that the provincial administration was poorly equipped to deal with the problems of delivering services to a population well in excess of 40 million. ${ }^{22}$ Banten was the obvious part of the province to split off; the Bantenese have a strong sense of their separate identity from the Sundanese who populate the highlands around Bandung, and the former have always resented their subservient position within a province where Sundanese are in a majority. Because of Banten's location to the west of Jakarta, district officials had to make long trips to the provincial capital in Bandung to bargain for resources. But as Quinn (2003:168) pointed out, the residency of Cirebon, which is close to Central Java, also felt ethnically different from the majority Sundanese. In addition, it has oil and gas reserves in the district of Indramayu. But it failed to gain provincial status because local elites were divided. Nor was the island of Madura successful in breaking away from East Java, at least partly because the province promised the island new development initiatives.

A more complicated saga unfolded in the province of Papua after 1998. Together with Aceh, this was the province which was most likely, following the example of East Timor, to demand a referendum on remaining part of Indonesia. It was also, like East Timor, a region where around 30 per cent of the non-agricultural labour force were employed as civil servants in 1996, which was a much higher percentage than in any other province. Nonagricultural employment opportunities outside the government sector were very limited. By 1998, the great majority of government employees were indigenous Papuans. The central government appeared to take the view that the most effective way of dealing with secessionist tendencies would be to promise more civil service jobs to educated Papuans, by splitting the existing province into three, and by creating more districts. This plan drew considerable criticism from many Papuans, who felt that it would simply exacerbate regional and tribal tensions.

22 In fact the population of West Java still exceeds 40 million, even without Banten; it remains the largest province in terms of population. 
In spite of the opposition, President Megawati issued a presidential decree in January 2003, which confirmed the creation of three provinces, although in doing so, she was ignoring the provisions of the special autonomy legislation. ${ }^{23}$ If the intention of the central government was to deal with secessionist tendencies with the promise of more divisions, then the strategy seemed to have worked. The decree 'set off a cascade of demands from local officials and their supporters' for more provinces (McGibbon 2004:51). Indeed Mietzner (2009:279) argued that if Jakarta had not intervened to prevent the formation of more new provinces after the creation of West Papua, at least five new provinces might have emerged. Instead, both provinces have been split into a much larger number of districts, each of which will have some control over their resource revenues. By early 2009, there were 28 kabupaten and one kota in Papua, and a further nine kabupaten and one kota in West Papua. Thus in the space of less than a decade the number of districts in Papua had increased from nine to 39 (Table 1). This was a much larger increase than in any other region.

Inevitably with so many new districts being created outside Java, the average population size has declined, whereas in Java it has increased slightly (Table 2). By 2009, the average population of a district in Java was more than three times the average in Sumatra, four times the average in Kalimantan and Sulawesi, and almost 15 times than in Papua. Five of the new provinces created since the departure of Soeharto (Maluku Utara, Papua Barat, Gorontalo, Sulawesi Barat, and Bangka Belitung) had populations in 2009 which were the same as, or smaller than, the average district size in Java. There has also been a considerable jump in the number of villages, compared with 19961997 (Table 3). This is probably the result of new districts being created, but it might also reflect the change in the function of village units compared with the Soeharto era. ${ }^{24}$

In their analysis of the motivations for forming new kabupaten and kota, Fitrani, Hofman and Kaiser (2005:64-7) point out that an argument made by advocates of division was that many districts outside Java were simply too large in terms of area, and that populations in isolated areas were unfairly denied access to services such as health and education. Certainly there has been a strong tendency for more divisions to occur in the lightly populated provinces outside Java. ${ }^{25}$ But even with the splitting of kota and kabupaten

23 A detailed discussion of the special autonomy legislation and its implications is given in Resosudarmo and Jotzo 2009, especially Chapter 2.

24 Law No. 22/1999 reflected the spirit of post-Soeharto Reformasi by permitting villages to revert to their traditional title (nagari in West Sumatra, marga in South Sumatra, and so on) and stipulated that the village is to be based on local origins and customs (Antlöv 2003:199). This is a reversal of Soeharto-era policies as set out in the 1979 law.

25 The logit regression model used by Fitrani, Hofman and Kaiser (2005) found that between 2001 and 2003 the more populous regions were less likely to split and that a large land area increased the probability of splitting. 
which has occurred, there were still several provinces in 2009 where the average district size was above 5,000 square kilometres, compared with 1,097 square kilometres in Java, The average size of a district in Papua and Papua Barat was over twice the national average and almost 10 times that of Java (Table 2). ${ }^{26}$ Most districts in Papua and Kalimantan still have low population densities compared with Java, Bali, West Nusatenggara and East Nusatenggara and some parts of Sumatra. Whether it will be possible to provide the scattered populations of these large districts with better access to services such as health and education remains to be seen.

It is probable that many people in more remote regions outside Java expected that splitting would lead to more transfers from the centre; this in turn encouraged local power brokers to demand the creation of new districts so that they could control more resources. Certainly the devolution of resources to the district level, where it has occurred, has made the job of district head (walikota or bupati) very attractive to those who in the past had only managed to achieve lower-level positions in provincial or regional bureaucracies, or who had been largely excluded from official positions. ${ }^{27}$ And the advent of popular elections meant that members of prominent local families could credibly present themselves as having more concern for the needs, whether economic, social or religious, of local populations who had felt neglected and marginalized under the old system.

That many district (kabupaten and kota) governments now have substantial resources from central government grants at their disposal is indisputable. The three major central government allocations to the regions have grown not just in absolute terms but relative to GDP between 2001 and 2006, although there was a slight decline between 2006 and 2008 (Table 5).

As a proportion of total government expenditures, they increased from 24 per cent in 2001 to 30 per cent in $2008 .^{28}$ This was a considerable increase over the old SDO, which were the central grants to the regions to cover administrative costs. While the DAU (general allocation) is the largest, the DAK (special allocations which are tied to designated sectors) and the DBH (sharing of resource revenues) have grown more rapidly and by 2008 accounted for almost 40 per cent of the total. The $\mathrm{DBH}$ allocations are made to those

26 Charras (2005: Table 6.1) points out that in 2003, after the creation of three new kabupaten in Papua, the average size of a kabupaten was still over 35,000 square kilometres, compared with less than 1,600 square kilometres in Java.

27 Malley (2003:107-8) states that in the early years of the Soeharto era, the majority of provincial and district heads (governors, mayors, and bupati) were from the military. Although the proportion dropped in the course of the 1980s, most appointees continued to be from either the civilian or the military bureaucracies with none from the business communities. Even those who supported Golkar were unable to secure appointments to senior positions.

28 Figures for 2001 are from Deuster (2002: Table 3) and for 2008 from Gunawan and Siregar (2009: Table 3). 
provinces with large mining and forestry sectors; in addition provinces and regions receive all revenues from the property tax and 20 per cent of income tax collections. ${ }^{29}$

Table 5. Central government allocations to regions: 2001-2008 (Rp. billion)

\begin{tabular}{lrrlrc}
\hline Year & DAU & DAK & DBH & Total $^{*}$ & Percentage of GDP \\
\hline 2001 & 60.3 & 0.7 & 20.0 & 81.5 & 4.8 \\
2002 & 69.1 & 0.7 & 24.2 & 97.9 & 5.4 \\
2003 & 77.0 & 2.6 & 27.9 & 120.7 & 6.0 \\
2004 & 82.1 & 3.7 & 37.4 & 130.0 & 5.7 \\
2005 & 88.7 & 4.7 & 49.8 & 153.4 & 5.5 \\
2006 & 145.7 & 11.6 & 59.6 & 219.4 & 6.6 \\
2007 & 164.8 & 17.1 & 68.5 & 254.2 & 6.4 \\
2008 & 179.5 & 20.8 & 78.6 & 292.6 & 5.9 \\
\hline
\end{tabular}

* The total exceeds the sum of the DAU, DAK and DBH as there are also 'special autonomy and adjustment' grants made to provinces.

Sources: Usman and Suryahadi (2008:11), with additional data from Deuster (2002: Table 2), Kenward (2004: Table 2) and Gunawan and Siregar (2009: Table 3); GDP data from Central Board of Statistics (2008: Table 11.9)

The DAU and DAK payments (like the old INPRES allocations) appear to be skewed to those provinces with small populations and low population densities. In 2006, per capita DAU and DAK allocations to most of the provinces in Eastern Indonesia were well above the average for the country as a whole (Table 6).

Both Papua and Papua Barat received per capita DAU and DAK allocations which were more than 10 times greater than those received by West Java. It is unlikely that the DBH allocations would greatly modify this disparity; while West Java, and other provinces in Java obtain more revenues from property and other taxes, Papua receives a share of the mining and forestry revenues. The new provinces formed in Eastern Indonesia (Gorontalo, West Sulawesi, Maluku Utara, and Papua Barat) all received higher DAU and DAK allocations per capita than the provinces from which they had split off. This supports the argument that splitting provinces and creating new districts have resulted in more transfers from the centre, at least outside Java.

It appears that the regions of Java have paid a penalty for preserving the stability of their borders, in that their per capita DAU and DAK allocations are (with the exception of Yogyakarta) very low in comparison with the national average. The one new province in Java, Banten, does not seem to

29 Soesastro and Atje (2005:30-2) discuss the revenue sharing system which emerged from Law Nos. 32 and 33, 2004. 
Table 6. Provinces ranked in terms of per capita DAU plus DAK allocations (x Rp 1000 per capita, 2006: provinces ranked from lowest to highest)

\begin{tabular}{|c|c|c|c|}
\hline Province & $\begin{array}{c}\text { Per capita } \\
\text { DAU plus DAK }\end{array}$ & $\begin{array}{c}\text { Headcount } \\
\text { poverty* }\end{array}$ & $\begin{array}{c}\text { Population } \\
\text { density }\end{array}$ \\
\hline Jakarta & 86 & 4.6 & 13,344 \\
\hline Banten & 315 & 9.8 & 1,044 \\
\hline West Java & 352 & 14.5 & 1,126 \\
\hline East Java & 479 & 21.1 & 757 \\
\hline Riau & 428 & 11.9 & 52 \\
\hline Central Java & 520 & 22.2 & 1,126 \\
\hline Lampung & 634 & 22.8 & 201 \\
\hline South Sumatra & 661 & 21.0 & 73 \\
\hline North Sumatra & 668 & 15.0 & 169 \\
\hline Yogyakarta & 761 & 19.2 & 1,049 \\
\hline West Nusatenggara & 773 & 27.2 & 208 \\
\hline East Kalimantan & 824 & 11.4 & 12 \\
\hline Riau Islands & 833 & 12.2 & 15 \\
\hline Bali & 900 & 7.1 & 601 \\
\hline South Sulawesi & 948 & 14.6 & 85 \\
\hline South Kalimantan & 1,109 & 15.2 & 28 \\
\hline Jambi & 1,118 & 11.4 & 49 \\
\hline East Nusatenggara & 1,153 & 29.3 & 90 \\
\hline West Sumatra & 1,208 & 12.5 & 106 \\
\hline West Kalimantan & 1,216 & 15.2 & 28 \\
\hline Aceh & 1,378 & 28.3 & 78 \\
\hline North Sulawesi & 1,422 & 11.5 & 134 \\
\hline West Sulawesi & 1,495 & 20.7 & 11 \\
\hline Central Sulawesi & 1,511 & 23.6 & 36 \\
\hline Bangka/Belitung & 1,532 & 10.9 & 65 \\
\hline Southeast Sulawesi & 1,606 & 23.4 & 51 \\
\hline Gorontalo & 1.638 & 29.1 & 75 \\
\hline Bengkulu & 1,654 & 23.0 & 78 \\
\hline Maluku & 2,135 & 33.0 & 27 \\
\hline Maluku Utara & 2,337 & 12.7 & 29 \\
\hline Kalimantan Tengah & 2,452 & 11.0 & 12 \\
\hline $\begin{array}{l}\text { Papua } \\
\text { Pant }\end{array}$ & 4,006 & 41.5 & 7 \\
\hline Papua Barat & 4,370 & 41.3 & 21 \\
\hline Indonesia & 704 & 17.8 & 116 \\
\hline
\end{tabular}

* percentage of the population in the province which is below the official poverty line in 2006 ** population per square kilometre, 2005

Sources: Data on DAU and DAK by province from www.bappenas.go.id (accessed 14-12-2008). Population density data from Central Board of Statistics (2008), Table 2.2. Poverty data from Central Board of Statistics (2008), Table 5.2. 
have benefited in terms of higher DAU and DAK allocations; in fact in 2006 such allocations were lower than in West Java (Table 6). The treatment of Java can be seen as a continuation of the INPRES allocation system, which also discriminated against Java. Whether it will provoke a reaction in terms of more splitting in Java remains to be seen. ${ }^{30}$

\section{Critical evaluations}

Beginning in 2001, a number of evaluations of the decentralization programme began to appear. Many were critical in tone. One of the earliest published evaluations pointed out that 'the laws and regulations defining expenditure assignment and revenue powers have been written in a relatively uncoordinated way by two different groups within government' (Alm, Aten and Bahl 2001:88). Schulte Nordholt (2004:38) suggested that this reflected a basic difference in the motivations behind the two laws; whereas Law No. 22 was designed to devolve power to the regions, Law No. 25 was more centralist in character, in that the main sources of taxation were kept firmly under central control. According to his analysis, the decentralization of administrative powers was in fact being heavily subsidized by the central government, and the legislation gave little incentive to either provincial or sub-provincial governments to increase their own-revenue effort. Other researchers pointed out that the decision to keep most of the lucrative taxes under central control has forced many district governments to rely more on taxes on the transport of goods which can have harmful effects on inter-regional trade. ${ }^{31}$

Early critics also pointed to the lack of clearly stated government objectives concerning equalization of fiscal capacities across local government. In addition, it was unclear how control of expenditure decisions should be divided between line ministeries and local governments (Alm, Aten and Bahl 2001:88). The allocation of funds was done on a 'hold harmless' basis so that all kabupaten and kota in 2001 received at least the same amount in nominal terms as they had done under the old system in 2000 (Lewis 2001:327). But Lewis pointed to a number of problems with the allocation methods that were being used by the Ministry of Finance which suggested that the general and special allocations (DAU and DAK) might aggravate rather than reduce regional disparities in fiscal capacities. Other commentators stressed that the new allocations through the DAU and the DAK gave kabupaten and kota much

30 For a discussion of the impact of the anti-Java bias on Java's willingness to support a united Indonesia, see Cribb 2001.

31 Such taxes were in wide use in many parts of the country until legislation passed in 1997 tried to curb them. This legislation was never popular with many regional governments and has been largely set aside in the post-2001 era (Ray and Goodpaster 2003:82-5). 
greater discretion than they had had under the old INPRES system where the grants tended to be earmarked for specific types of infrastructure. The block grant system through the DAU and DAK gave local governments much more latitude and it was far from clear how they would use their new powers, or what sanctions the central government could use if the funds were obviously misused (Silver, Azis and Schroeder 2001:358-9).

Table 7. DAU and DAK allocations (2006) correlated with various indicators

\begin{tabular}{lcc}
\hline & \multicolumn{2}{c}{ Correlation coefficients } \\
\hline Indicators & All provinces & Outside Java \\
\hline Headcount poverty & 0.548 & 0.436 \\
Per capita expenditures & -0.490 & -0.279 \\
RGDP per capita & -0.369 & -0.231 \\
Population densities & -0.798 & -0.516 \\
Population 2006 & -0.727 & -0.717 \\
HDI & -0.467 & -0.390 \\
\hline
\end{tabular}

Sources: Data on DAU and DAK by province from www.bappenas.go.id (accessed 14-12-2008). Per capita expenditures from Central Board of Statistics (2008), Table 4.3. Poverty data from Central Board of Statistics (2008: Table 5.2). Population density data from Central Board of Statistics (2008: Table 2.2). HDI (Human Development Index) from Central Board of Statistics (2008: Table 3.8). Regional GDP data from Central Board of Statistics (2008: Table 11.12).

From 2001 onwards, fears have been expressed that the decentralization process would cause poorer, more remote regions to fall further behind those with greater endowments of natural resources or other locational advantages (Schulte Nordholt 2004:39). These fears so far are only partially supported by the evidence. Some of the poorer provinces outside Java (in terms of headcount measures of poverty) have received higher per capita DAU and DAK allocations; this was particularly the case in Maluku and Papua. In 2006, there was a significant degree of positive correlation at the provincial level between per capita DAU and DAK allocations and the headcount measure of poverty, and negative correlation between these allocations and the provincial human development index (HDI) (Table 7). But not all poor regions seem to have benefited from greater DAU and DAK allocations. West Nusatenggara which has historically been a poor region, and has scored badly on indicators such as infant mortality rates, receives less than its more affluent neighbour, Bali. Central and East Java also have higher proportions of the population under the poverty line than the national average, and they too receive very low average DAU/ DAK allocations. ${ }^{32}$ And skewing more resources to poorer provinces and dis-

32 Further discussion of the way the allocations favour some regions with little poverty over those with much larger numbers of poor people is given in Fane (2003:169-70). 
tricts does not mean that they will be used to benefit poorer people. We need many more detailed case studies of particular districts before a firm conclusion on the poverty alleviation impact of the post-2001 system can be reached. ${ }^{33}$

A number of studies have argued that the main beneficiaries of the decentralization process, at least in its first decade have been 'local elites' in the district bureaucracies and parliaments who have used the greater resources accruing to the districts to boost their own salaries and perquisites, rather than to improve service provision in sectors such as health and education. Critics have pointed to the fact that in many parts of the country, former civil servants were successful in winning elections at kabupaten and kota levels. It is argued that such people were still imbued with 'New Order' values and would use the resources at their disposal for self-enrichment, or for boosting the incomes and status of narrow sections of the population, rather than for projects designed to benefit the poorer and less advantaged. In addition, several commentators suggested that many kabupaten and kota governments, especially outside Java, lacked the administrative capacity to implement antipoverty programmes, even if they might wish to do so.

There is certainly evidence to support such allegations. One recent study of eight districts in Java, Sumatra, Bali and West Nusatenggara found that 'many public sector jobs, government contracts and party-list positions have continued to be allocated on the basis of non-transparent, elite-centric agreements' (von Luebke 2009:226). Also worrying is the rise of money politics at the local level; one former governor from the Soeharto era has pointed out that 'a candidate without money will almost surely not be elected' (Mboi 2009:47). To the extent that candidates in the local elections are spending large sums of money on their campaigns, and cannot be sure of more than one term in office, they have obvious incentives to make as much money as possible as quickly as possible, especially from government contracts. Especially in those regions, mainly outside Java, where government contracts are the main source of income for private contractors, the scope for corrupt deals between government officials and contractors is likely to be considerable. ${ }^{34}$

In defence of the decentralization process and the introduction of direct elections of local officials, it can be argued that corrupt dealings between local officials, both military and civilian, and business groups were hardly

33 Rasyid (2003:68), who played a key role in framing the 1999 legislation, has stated that the DAK allocations were intended to assist poorer regions in improving provision of services such as health, education, transport and water supply. But it appears that some districts have had problems using the funds allocated. For a discussion of the problems experienced by several districts in using the DAK allocations, see in particular Newsletter No. 25, SMERU Research Institute, January-April 2008 (www.smeru.or.id).

34 Hidayat (2009) gives several case studies of the way in which powerful business interests have captured provincial and district governments, especially since the introduction of direct election of local officials. Particularly interesting is his study of Banten. 
unknown in the Soeharto era. Those who support the development of democratic processes at the local level argue that only with greater transparency and greater monitoring of official behaviour by non-governmental agencies and the press can corrupt practices be reduced, if not eliminated. Better accounting procedures at the local level and stronger audit mechanisms are also essential, but these require skilled officials, and it will take time to train them. In the meantime, the absence of trained officials at the district level is being used by some provinces outside Java to support a larger proportion of the central grants being allocated to, and disbursed by, the provinces. ${ }^{35}$

\section{Conclusions}

This article has argued that the post-Soeharto changes in regional and local government in Indonesia can be seen as a reaction to the autocratic centralization policies of the Soeharto regime, which in turn were a reaction to the 'de facto' federalism of the 1960s. A serious attempt had been made in the mid1950s to introduce a transparent system of centre-regional financial relations in Indonesia which met, at least partially, the grievances of the resource-rich provinces outside Java. These grievances were in turn a legacy of the colonial era. But the opportunity to correct historical injustices was missed, and to many outside Java the Soeharto-era policies were little more than a continuation of colonial policies which looted the resource wealth of the regions outside Java, and gave little back in return.

The legacy of the Soeharto era was a system of regional and local government which, while it conferred some benefits in terms of improved infrastructure and access to education and health care, possessed little legitimacy in the eyes of many Indonesians. Especially outside Java, where regional and local government units had been less well defined than in Java in the colonial era, boundaries were often fluid and contested. Even after the splitting of provinces and the creation of new district and sub-district levels of government in the 1950s and early 1960s, many regions outside Java were much larger and far more lightly populated than their counterparts in Java. They also encompassed, in many cases, different ethnic and religious groups. The transmigration schemes of the 1980s often aggravated the problems by settling Javanese and Madurese families on land which was not infrequently claimed by indigenous populations.

35 One study has pointed out that the central government still retains considerable control over staffing policies at the district level including the number of posts and promotion procedures. Also the content of training courses is largely determined at the centre (Turner, Imbaruddin and Sutiyono 2009). 
The decentralization process and the creation of new provinces, districts and lower local government units outside Java were a reaction to these perceived inequalities and injustices. These changes were the result of a complex set of political, socio-cultural and economic forces which surfaced after the departure of Soeharto (Charras 2005:104). But many at the centre are still resisting change, and there have been some signs that central departments are trying to reclaim authority over some categories of public expenditure, or at the very least giving stronger directions to provincial and local governments on expenditure priorities. Lewis and Chakeri (2004: Table 4) pointed out that in 2001, at the start of the decentralization process, central government funds still accounted for a considerable share of total expenditures in sectors such as education. This was in spite of the fact that education was one sector where funding had supposedly been delegated to regions. Whether this would still be the case in 2009 is unclear. ${ }^{36}$

What is clear after eight years is that central government budgetary allocations to the regions are substantial, at around six per cent of GDP, and comprise a large part of the total resources available to most kabupaten and $k o t a$. Just how large a part is difficult to ascertain, because information on own-revenue effort at the provincial and sub-provincial levels has not been published since 2001, and indeed provincial and district governments are clearly reluctant to furnish central agencies with accurate data. The central government should have considerable leverage over regional governments, simply by threatening to withdraw grants if they refuse to supply evidence on revenues and expenditures, or if there is clear evidence that the regions either cannot spend the money or are using it for dubious purposes.

Who is to decide whether the expenditure priorities of around 500 districts are in accordance with the spirit of the 1999 legislation? This is still a contentious issue, especially as the legislation made no explicit provision for audit procedures. In some parts of the country, NGOs appear to have assumed the role of informal auditors of at least some aspects of expenditure policy. While this may be desirable in a democratic environment, NGOs should not be permitted to replace independent professional auditors. Where the splitting process has produced kabupaten and kota which have small populations, and which lack much technical or administrative capacity, it is inevitable that provincial governments will have to take the leading role in expenditure decisions and project implementation, even if this goes against the spirit, and

36 The revised draft of the 2009 national budget almost doubled the allocation to the education sector, although fears have been expressed about the central government's capacity to spend the money, and turf wars have emerged between the Badan Perencanaan Pembangunan Nasional (Bappenas, National Planning Agency) and the Department of Education (Ashcroft and Cavanough 2008:351). Clearly many in the central government still believe that educational policy is far too important to be left to the regions, even though there are ongoing disputes about who in the central government should control the funds. 
indeed the letter, of the 1999 legislation. At the end of the day, the success of Indonesia's great experiment in decentralization will rest on the ability of provinces and districts to supply the services people need, and on the extent to which local populations can control the behaviour of officials through public scrutiny of their decisions and through the electoral process. This may be easier in smaller units than in larger ones.

\section{References}

Alm, James, Robert Aten and Roy Bahl

2001 'Can Indonesia decentralise successfully? Plans, problems and prosAntlöv, Hans pects', Bulletin of Indonesian Economic Studies 37-1:83-102.

2003 'Village government and rural development in Indonesia: The new democratic framework', Bulletin of Indonesian Economic Studies 39-2:193214.

Ashcroft, Vincent and David Cavanough

2008 'Survey of recent developments', Bulletin of Indonesian Economic Studies 44-3:335-63.

Asher, M. and Anne Booth

1992

'Fiscal policy', in: Anne Booth (ed.), The oil boom and after: Indonesian economic policy and performance in the Soeharto era, pp. 41-76. Singapore: Oxford University Press. [South-East Asian Social Science Monographs.]

Aspinall, Edward and Greg Fealy (eds)

2003 Local power and politics in Indonesia: Decentralisation and democratisation. Singapore: Institute of Southeast Asian Studies. [Indonesia Updates Se-

Booth, Anne ries.]

1996 'Intergovernmental relations and fiscal policy in Indonesia: The national impact of equity and inequity in the provinces', in: Christine Fletcher (ed.), Equity and development across nations: Political and fiscal realities, pp, 180-205. Sydney: Allen and Unwin.

2003 'Decentralisation and poverty alleviation in Indonesia', Environment and Planning C: Government and Policy 21:181-202.

2004 'Africa in Asia? The development challenges facing eastern Indonesia and East Timor', Oxford Development Studies 32-1:19-36.

Central Board of Statistics

2008 Trends of the selected socio-economic indicators of Indonesia. Jakarta: Central Board of Statistics. www.bps.go.id (accessed 14-12-2008).

Central Board of Statistics

2009 Trends of the selected socio-economic indicators of Indonesia. Jakarta: Central Board of Statistics. www.bps.go.id (accessed 4-3-2009).

Central Bureau of Statistics

1963 Sensus penduduk 1961 Republik Indonesia angka2 sementara. Jakarta: Central Bureau of Statistics. 
Central Bureau of Statistics

1996 Produk domestik regional bruto kabupaten/kotamadya 1993-95. Jakarta: Central Bureau of Statistics.

Central Bureau of Statistics

1997 Penduduk Indonesia: Hasil survei penduduk antar sensus 1995. Jakarta: Central Bureau of Statistics.

Charras, Muriel

2005 'The reshaping of the Indonesian archipelago after 50 years of regional imbalance', in: Maribeth Erb, Carole Faucher and Priambudi Sulistiyanto (eds), Regionalism in post-Suharto Indonesia, pp, 88-108. London:

Chauvel, Richard RoutledgeCurzon. [Contemporary Southeast Asian Series.]

1997

'Tarred with the Dutch brush: The fate of federalism in Indonesia', in: P.J. Drooglever and M.J.B. Schouten (eds), De leeuw en de banteng: Bijdragen aan het Congres over de Nederlands-Indonesische betrekkingen 1945-1950, gehouden in Den Haag van 27-29 maart 1996, pp. 43-60. Den Haag: Instituut voor Nederlandse Geschiedenis.

Cribb, Robert

2001 'Independence for Java? New national projects for an old empire', in: Grayson Lloyd and Shannon Smith (eds), Indonesia today: The challenges of history, pp. 298-307. Singapore: Institute of Southeast Asian Studies. [Indonesia Assessment Series 7.]

Department of Information

1993 Lampiran pidato pertanggungjawaban Presiden/Mandataris Majelis Permusyawaratan Rakyat, 1 Maret 1993. Jakarta: Department of Information.

Department of Information

1998 Lampiran pidato kenegaraan Presiden Republik Indonesia di depan Sidang Dewan Perwakilan Rakyat, 15 Agustus 1998. Jakarta: Department of Information.

Deuster, Paul

2002

'Survey of recent developments', Bulletin of Indonesian Economic Studies 38-1:5-37.

Erb, Maribeth, Carole Faucher and Priambudi Sulistiyanto (eds)

2005 Regionalism in post-Suharto Indonesia. London: RoutledgeCurzon. [Contemporary Southeast Asia Series.]

Erb, Maribeth and Priambudi Sulistiyanto (eds)

2009 Deepening democracy in Indonesia? Direct elections for local leaders (Pilkada).

Fane, George

Singapore: Institute of Southeast Asian Studies.

2003 'Change and continuity in Indonesia's new fiscal decentralisation arFeith, Herbert

rangements', Bulletin of Indonesian Economic Studies 39-2:159-76.

1962 The decline of constitutional democracy in Indonesia. Ithaca, NY: Cornell University Press.

Fitrani, Fitria, Bert Hofman and Kai Kaiser

2005 'Unity in diversity? The creation of new local governments in a decentralising Indonesia', Bulletin of Indonesian Economic Studies 41-1:57-79. 
Ford, Michelle

2003 'Who are the Orang Riau? Negotiating identity across geographic and ethnic divides', in: Edward Aspinall and Greg Fealy (eds), Local power and politics in Indonesia: Decentralisation and democratisation, pp, 132-47. Singapore: Institute of Southeast Asian Studies. [Indonesia Update Series.]

Gunawan, Anton and R. Siregar

2009 'Survey of recent developments', Bulletin of Indonesian Economic Studies 45-1:9-38.

Hidayat, Syarif

2009 'Pilkada, money politics, and the dangers of "informal governance" practices', in: Maribeth Erb and Priambudi Sulistiyanto (eds), Deepening democracy in Indonesia? Direct elections for local leaders (Pilkada), pp. 125Hill, Hal (ed.)

46. Singapore: Institute of Southeast Asian Studies.

1989 Unity in diversity: Regional economic development in Indonesia since 1970. Singapore: Oxford University Press. [South-East Asian Social Science Monographs.]

Holland, Peter

1999 'Regional government and central authority in Indonesia', in: Timothy Lindsey (ed.), Indonesia: Law and society, pp. 200-20. Sydney: Federation Press.

Ide Anak Agung Gde Agung

1996 From the formation of the state of East Indonesia towards the establishment of the United States of Indonesia. Translated by Linda Owens. Jakarta: Yayasan Obor Indonesia. [Originally published as Dari negara Indonesia Timur ke Republik Indonesia Serikat. Yogyakarta: Gadjah Mada University Press, 1985.]

Kahin, Audrey

1999 Rebellion to integration: West Sumatra and the Indonesian polity. Amsterdam: Amsterdam University Press

Kahin, George McTurnan

1952 Nationalism and revolution in Indonesia. Ithaca, NY: Cornell University Press.

Kell, Tim

1995

Kenward, Lloyd

The roots of the Acehnese rebellion, 1989-1992. Ithaca, NY: Cornell Modern Indonesia Project, Southeast Asia Program.

2004 'Survey of recent developments', Bulletin of Indonesian Economic Studies 40-1:9-35.

Kimura, Ehito

2007 'Marginality and opportunity in the periphery: The emergence of Gorontalo Province in North Sulawesi', Indonesia 84:71-95.

Kingsbury, Damien and Harry Aveling (eds)

2003 Autonomy and disintegration in Indonesia. London: RoutledgeCurzon.

Kong, Tao and Arief Ramayandi

2008 'Survey of recent developments', Bulletin of Indonesian Economic Studies 44-1:7-32. 
Legge, J.D.

1961 Central authority and regional autonomy in Indonesia: A study in local administration 1950-60. Ithaca, NY: Cornell University Press.

Lev, Dan

1996 'Between state and society: Professional lawyers and reform in Indonesia', in: Daniel S. Lev and Ruth McVey (eds), Making Indonesia: Essays on modern Indonesia in honor of George McT. Kahin, pp. 144-63. Ithaca, NY: Southeast Asia Program, Cornell University. [Studies on Southeast Asia 20.]

Lewis, Blane D.

2001 'The new Indonesian equalisation transfer', Bulletin of Indonesian Economic Studies 37-3:325- 43.

Lewis, Blane D. and Jasmin Chakeri

2004 'Central development spending in the regions post-decentralisation', Bulletin of Indonesian Economic Studies 40-3:379-94.

Luebke, Christian von

2009 'The political economy of local governance: Findings from an Indonesian field study', Bulletin of Indonesian Economic Studies 45-2:201-229.

McGibbon, Rodd

2004 'Plural society in peril: Migration, economic change and the Papua conflict', Policy Studies 13, Washington: East-West Center.

Mackie, J.A.C.

1980 'Integrating and centrifugal factors in Indonesian politics since 1945', in: J.A.C. Mackie (ed.), Indonesia: The making of a nation, pp. 669-84. Canberra: Research School of Pacific Studies, Australian National University. [AusMalley, Michael S. tralian Perspectives 3.]

2003 'Old structures and the limits of democratic decentralisation', in: Edward Aspinall and Greg Fealy (eds), Local power and politics in Indonesia, Marks, Stephen V. pp. 102-16. Singapore: Institute of Southeast Asian Studies.

2009 'Economic policies of the Habibie presidency: A retrospective', Bulletin of Indonesian Economic Studies 45-1:39-60.

Maryanov, Gerald S.

1958 Decentralization in Indonesia as a political problem. Ithaca, NY: Modern Indonesia Project, Southeast Asia Program, Department of Asian Studies, Cornell University. [Interim Report Series.]

1959 The establishment of regional government in the Republic of Indonesia. PhD thesis, Indiana University, Bloomington.

Mboi, A.B.

2009 'The first step on the long road to a dualistic provincial and district government', in: Maribeth Erb and Priambudi Sulistiyanto (eds), Deepening democracy in Indonesia? Direct elections for local leaders (Pilkada), pp. 38-52. Singapore: Institute of Southeast Asian Studies.

Mietzner, Marcus

2009 'Autonomy, democracy and internal donflict: The 2006 gubernatorial elections in Papua', in: Maribeth Erb and Priambudi Sulistiyanto (eds), Deepening democracy in Indonesia? Direct elections for local leaders (Pilkada), pp. 259-82. Singapore: Institute of Southeast Asian Studies. 
Miller, Michelle Ann

2006 'What's special about special autonomy in Indonesia', in: Anthony Reid (ed.), Verandah of violence: The background to the Aceh problem, pp. 292-314. Singapore: Singapore University Press.

Morishita, Akiko

2008 'Contesting power in Indonesia's resource-rich regions in the era decentralization: New strategy for central control over the regions', Indonesia 86:81-107.

Mubyarto and Revrisond Baswir

1989 'Central Kalimantan: The Dayak heartland', in: Hal Hill (ed.), Unity in diversity: Regional economic development in Indonesia since 1970, pp. 502-10. Singapore: Oxford University Press. [South-East Asian Social Science Monographs.]

Nasution, Adnan Buyung

1992 The aspiration for constitutional government in Indonesia: A socio-legal study of the Indonesian Konstituante 1956-1959. Jakarta: Sinar Harapan.

Niessen, Nicole

1999 Municipal government in Indonesia: Policy, law, and practice of decentralization and urban spatial planning. Leiden: Research School CNWS, School of Asian, African, and Amerindian Studies, Universiteit Leiden. [CNWS Publications 17.]

Paauw, Douglas

1960 Financing economic development: The Indonesian case. Glencoe: The Free Press.

Pangestu, Mari and Iwan J. Azis

1994 'Survey of recent developments', Bulletin of Indonesian Economic Studies 30-2: 3-47.

Patten, Richard H., Belinda Dapice and Walter Falcon

1980 'An experiment in rural employment creation: The early history of Indonesia's kabupaten development programme', in: Gustav F. Papanek Quinn, George (ed.), The Indonesian economy, pp. 155-82. New York: Praeger.

2003 'Coming apart and staying together at the centre: Debates over provincial status in Java and Madura', in: Edward Aspinall and Greg Fealy (eds), Local power and politics in Indonesia, pp. 164-78. Singapore: Institute Rasyid, M. Ryaas of Southeast Asian Studies. [Indonesia Update Series.]

2003 'Regional autonomy and local politics in Indonesia', in: Edward Aspinall and Greg Fealy (eds), Local power and politics in Indonesia, pp. 63-71. Singapore: Institute of Southeast Asian Studies. [Indonesia Update Series.]

Ray, David and Gary Goodpaster

2003 'Indonesian decentralization: Local autonomy, trade barriers and discrimination', in: Damien Kingsbury and Harry Aveling (eds), Autonomy and disintegration in Indonesia, pp. 75-95. London: RoutledgeCurzon 
Resosudarmo, Budy P. and Frank Jotzo (eds)

2009

Working with nature against poverty: Development, resources and the environment in eastern Indonesia. Singapore: Institute of Southeast Asian Studies.

Roth, Dik

2007

'Many governors, no province: The struggle for a province in the Luwu-Tanah Toraja area in South Sulawesi', in: Henk Schulte Nordholt and Gerry van Klinken (eds), Renegotiating boundaries: Local politics in post-Suharto Indonesia, pp. 121-50. Leiden: KITLV Press. [Verhandelingen 238.]

Sakai, Minako (ed.)

2002 Beyond Jakarta: Regional autonomy and local societies in Indonesia. Adelaide: Crawford House.

Schulte Nordholt, Henk

2004 'Decentralization in Indonesia: Less state, more democracy', in: John Harriss, Kristian Stokke and Olle Törnquist (eds), Politicising democracy: The new local politics of democratisation, pp. 29-50. Basingstoke: Palgrave.

Schulte Nordholt, Henk, and Gerry van Klinken (eds)

2007 Renegotiating boundaries: Local politics in post-Suharto Indonesia. Leiden:

KITLV Press. [Verhandelingen 238.]

Shah, Anwar and Zia Qureshi

1994 'Inter-governmental fiscal relations in Indonesia: Issues and reform options', World Bank Discussion Paper No. 239, Washington: World Bank.

Silver, Christopher, Iwan J. Azis and Larry Schroeder

2001 'Intergovernmental transfers and decentralisation in Indonesia', Bulletin of Indonesian Economic Studies 37-3:345-62.

Smith, Claire Q.

2009 'The return of the Sultan? Patronage, power and political machines in "post"-conflict North Maluku', in: Maribeth Erb and Priambudi Sulistiyanto (eds), Deepening democracy in Indonesia? Direct elections for local leaders (Pilkada), pp. 303-26. Singapore: Institute of Southeast Asian Studies.

Soesastro, Hadi and Raymond Atje

2005 'Survey of recent developments', Bulletin of Indonesian Economic Studies 41-1:5-34.

Taylor, A.D.

$1960 \quad$ Indonesian independence and the United Nations. London: Stephens.

Turner, Mark, Amir Imbaruddin and Wahyu Sutiyono

2009 'Human resource management: The forgotten dimension of decentralization in Indonesia', Bulletin of Indonesian Economic Studies 45-2:231-49.

Usman, Syaikhu and Asep Suryahadi

2008

'The development of DAK allocation and its relationship with infrastructure condition', Newsletter No. 25, SMERU Research Institute, Janu-

Wit, Y. de ary-April 2008 (www.smeru.or.id).

1973

'The kabupaten programme', Bulletin of Indonesian Economic Studies 9-1:65-85. 